\title{
INTEGRITAS :JurnalPengabdian
}

Vol 3, No 1, Juli 2019

ISSN 2580-7978 (Cetak) ISSN 2615-0794 (Online)

\section{Pembuatan Minuman Herbal Instan di Kelurahan Banyumanik Kota Semarang}

\section{The Production of Instant Herbal Drinks in Banyumanik Village, Semarang}

\author{
Iffah Muflihati ${ }^{1)}$, Arief Rakhman Affandi ${ }^{2)}$

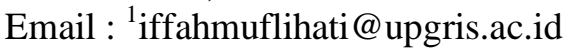 \\ ${ }^{1,2}$ Universitas PGRI Semarang
}

\begin{abstract}
Banyumanik Sub-district especially $R W I V$ and $R W V$ have potential Family Welfare Program members to be empowered economically through food processing program. The problem faced is the availability of herbs in the yard that have not been utilized. The housewives have an interest in producing processed products from herbal plants that are easy to handle and have a long shelf life. This IbM service activity aims to empower housewives in RW IV and RW V, Banyumanik Village, Banyumanik District, Semarang City through the processing of instant herbal drink program. Outputs that will be generated from this service include Family Welfare Program membership documents, processed instant beverage products from herbal plants with known nutritional content, trademarks, and numbers of home industry food circulating in minimarkets and gift shops. This activity is carried out through the stages of socialization, training of processing of herbal plants into instant drinks, analysis of nutrient content, home industry food licensing, and evaluation. The results obtained are the ability of the participans to process herbal plants (ginger, kencur and turmeric) into instant beverage products (instant ginger, instant kencur rice, and instant sour turmeric).
\end{abstract}

Keywords: service, instant drinks, training, partners, housewives

\begin{abstract}
Abstrak :KelurahanBanyumanik khususnya RW IV dan RW V memiliki anggota PKK yang potensial untuk diberdayakan secara ekonomi melalui pengolahan bahan makanan. Permasalahan yang dihadapai adalah ketersediaan tanaman herbal di pekarangan yang belum termanfaatkan. Para ibu rumah tangga memiliki keinginan untuk menghasilkan produk olahan dari tanaman herbal yang memiliki kemudahan dalam penanganan dan memiliki umur simpan yang lama. Kegiatan pengabdian IbM ini bertujuan untuk memberdayakan para ibu rumah tangga di RW IV dan RW V Kelurahan Banyumanik Kecamatan Banyumanik Kota Semarang melalui pengolahan minuman herbal instan. Luaran yang akan dihasilkan dari pengabdian ini antara lain dokumen keanggotaan PKK, produk olahan minuman instan dari tanaman herbal yang telah diketahui kandungan gizinya, merk dagang, dan nomor PIRT yang beredar di minimarket dan toko oleh-oleh. Kegiatan ini dilakukan melalui tahapan sosialisasi, pelatihan pengolahan tanaman herbal menjadi minuman instan, analisis kandungan zat gizi, perizinan PIRT, dan evaluasi. Hasil yang didapatkan yaitu peserta pengabdian memiliki kemampuan mengolah tanaman herbal (jahe, kencur dan kunyit) menjadi produk minuman instan (jahe instan, beras kencur instan, dan kunyit asam instan).
\end{abstract}




\section{INTEGRITAS :JurnalPengabdian}

Vol 3, No 1, Juli 2019

ISSN 2580-7978 (Cetak) ISSN 2615-0794 (Online)

Kata kunci : pengabdian, minuman instan, pelatihan, mitra, ibu rumah tangga

\section{PENDAHULUAN}

Kelurahan Banyumanik adalah salah satu kelurahan yang ada di Kecamatan Banyumanik, Kota Semarang. Dari berbagai program kerja di bidang pangan yang telah dilakukan oleh Tim PKK Kelurahan Banyumanik, belum ada program yang menyentuh tentang pengolahan tanaman herbal menjadi produk olahan yang memiliki nilai ekonomi yang lebih tinggi. Sementara jumlah tanaman herbal yang ada di Kelurahan Banyumanik cukup melimpah sehingga jika dioptimalkan pemanfaatannya akan menambah nilai ekonomi dari tanaman tersebut.

Ibu-ibu rumah tangga Kelurahan Banyumanik pernah mengolah jahe menjadi sirup jahe, namun kualitas yang didapatkan kurang baik dan mengalami kesulitan dalam pengemasan dan penyimpanan. Hal ini disebabkan karena sirup jahe berbentuk cairan sehingga faktor penanganan menjadi hal yang perlu diperhatikan. Melihat fakta tersebut, maka pengolahan tanaman herbal dapat diarahkan menjadi produk yang memiliki umur simpan lebih panjang, seperti minuman instan. Minuman instan yang dapat dibuat antara lainjahe instan, beraskencurinstan, dankunyitasam instan. Ibu-ibu PKK di Kelurahan Banyumanik cukup aktif dalam pertemuan dan pelaksanaan program PKK yang telah disusun. Dalam pertemuan tersebut beberapa usulan dikemukakan, diantaranya adalah keinginan dari para ibu untuk mengolah tanaman herbal menjadi produk olahan yang lebih mudah penanganan dan memiliki umur simpan yang lebih lama. Selain proses pengolahan, para ibu rumah tangga di Kelurahan Banyumanik juga menginginkan hasil olahan tanaman herbal dapat dipasarkan.

Untuk dapat memasarkan produk tersebut, maka diperlukan sistem pengolahan yang baik, pengemasan yang baik, hingga pemberian merk dagang dan pendaftaran PIRT. Selama ini para ibu di Kelurahan Banyumanik belum mendapatkan bekal mengenai hal tersebut sehingga mereka perlu dibekali ilmu dan keterampilan mulai dari pengolahan tanaman herbal dalam bentuk minuman instan, cara pengemasan, pendaftaran PIRT, hingga cara pemasarannya. Selain itu, 


\section{INTEGRITAS :JurnalPengabdian}

Vol 3, No 1, Juli 2019

ISSN 2580-7978 (Cetak) ISSN 2615-0794 (Online)

untuk mengetahui kandungan gizi pada produk yang dihasilkan, analisis kandungan gizi dapat dilakukan sehingga hasilnya dapat dicantumkan pada label kemasan.

\section{TARGET DAN LUARAN}

Beberapa permasalahan yang ditemukan, solusi beserta luaran yang dapat ditawarkan antara lain

1. Permasalahan $1:$ kemampuan dalam manajemen anggota kelompok Solusi : untuk Mitra I (anggota PKK RW IV) dan Mitra II (anggota PKK RW V) perlu dimantapkan kembali struktur organisasi dan keanggotaan. Agar organisasi dapat berfungsi secara maksimal perlu dijelaskan kembali tugas pokok dan tanggung jawab masing-masing bagian. Hal ini dilakukan guna pembentukan sistem yang solid di dalam struktur organisasi PKK sehingga pelaksana pengabdian juga lebih mudah dalam memberikan koordinasi untuk pemecahan masalah mitra selanjutnya.

Luaran : dokumen yang berisi struktur keanggotaan PKK. Dalam dokumen tersebut juga berisi mengenai tugas pokok dan fungsi beberapa jabatan atau pemangku tanggung jawab.

2. Permasalahan2 : kreativitas dalam pengolahan tanaman herbal menjadi produk pangan olahan.

Solusi : untuk Mitra I (anggota PKK RW IV) perlu dikembangkan produk olahan tanaman herbal dalam bentuk minuman instan melalui proses pengolahan yang tepat. Dalam pengolahan tanaman herbal perlu dijelaskan juga jenis-jenis tanaman herbal yang dapat diolah menjadi minuman instan sehingga variasi produk yang dihasilkan lebih banyak. Sirup jahe yang sebelumnya telah diolah dapat dievaluasi kembali mengenai kelayakannya dari segi kualitas. Untuk Mitra II (anggota PKK RW V) perlu diperkenalkan dari awal mengenai tanaman herbal, manfaat, serta cara pengolahan tanaman herbal. Pada tahapan ini dapat ditekankan mengenai pengolahan tanaman herbal menjadi minuman instan. 


\section{INTEGRITAS :JurnalPengabdian}

Vol 3, No 1, Juli 2019

\section{ISSN 2580-7978 (Cetak) ISSN 2615-0794 (Online)}

Luaran : produk minuman herbal instan dengan berbagai variasi bahan baku (misalnya jahe instan, temulawak instan, kunyit asam instan, beras kencur instan, dan lain sebagainya).

3. Permasalahan 3 : pengetahuan dalam mengukur kandungan gizi produk yang dihasilkan

Solusi : untuk Mitra I (anggota PKK RW IV) dan Mitra II (anggota PKK RW V) perlu diberikan pengetahuan mengenai komponen zat gizi utama yang kandungannya harus ada di dalam produk pangan. Untuk itu produk yang dihasilkan perlu dianalisis kadar proksimatnya (air, karbohidrat, protein, lemak, dan abu).

Luaran : produk minuman herbal instan yang telah diketahui kandungan air, karbohidrat, protein, lemak, dan abu.

4. Permasalahan 4 : pengetahuan mengenai regulasi pangan (berkaitan dengan merk dagang dan PIRT).

Solusi : untuk Mitra I (anggota PKK RW IV) perlu diberi pengetahuan mengenai cara pelabelan yang tepat dengan melihat pelabelan yang pernah dilakukan pada sirup jahe sehingga dari hasil perbaikan bisa diimplementasikan pada minuman herbal instan. Sedangkan untuk Mitra II (anggota PKK RW V) diberikan penjelasan terperinci mengenai sistem pengemasan yang baik serta konsep pelabelan untuk produk pangan. Untuk kedua mitra juga dibekali tahapan cara menerbitkan PIRT.

Luaran : merk dagang, label kemasan, dan nomor PIRT. 


\section{INTEGRITAS :JurnalPengabdian}

Vol 3, No 1, Juli 2019

ISSN 2580-7978 (Cetak) ISSN 2615-0794 (Online)

\section{METODE PELAKSANAAN}

Secara skematis, metode pelaksanaan IbM dapat dilihat pada Gambar 1.

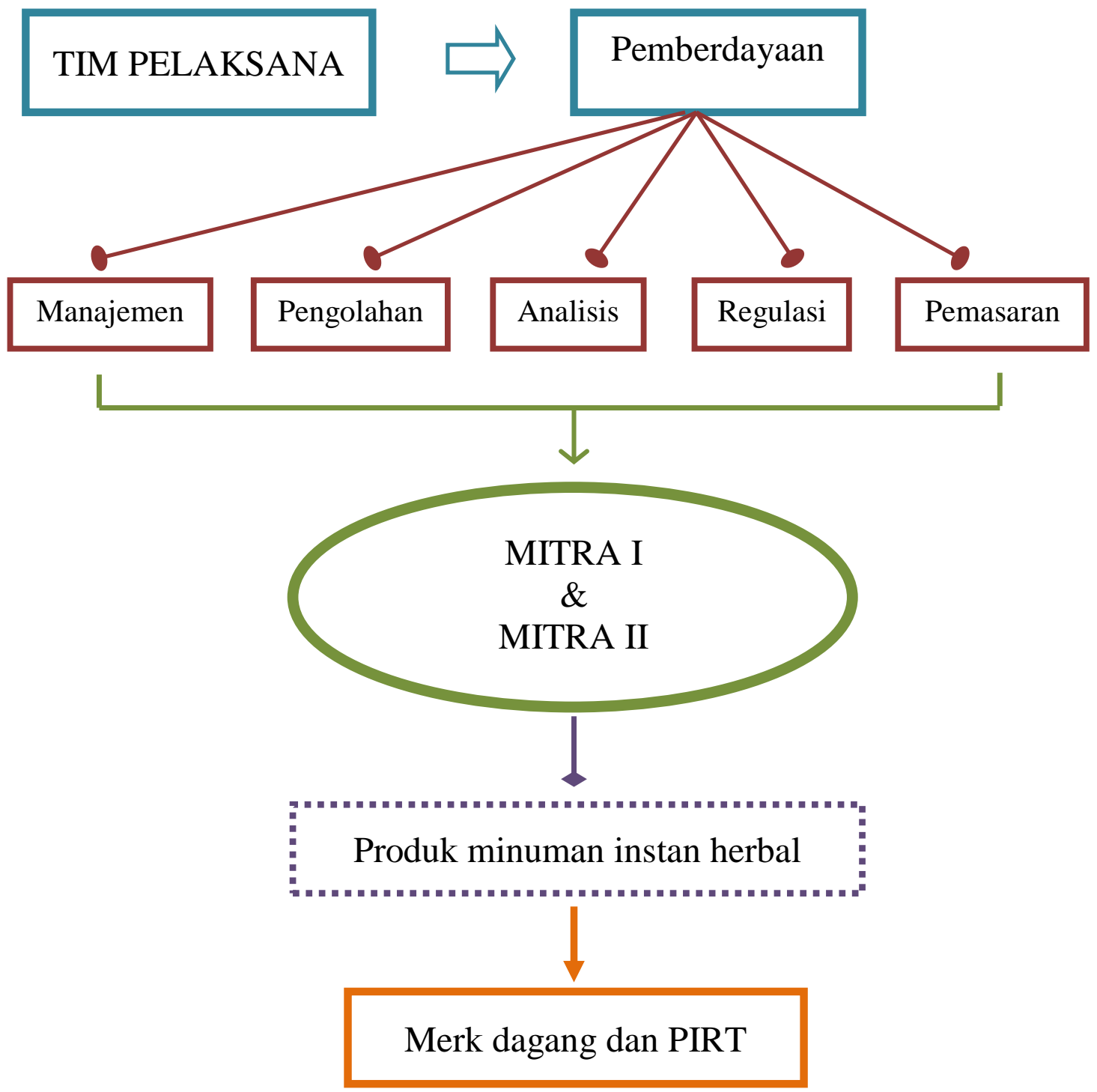

Gambar 1. Metode Pelaksanaan IbM

Metode pendekatan yang digunakan dalam pelaksanaan pengabdian yaitu pemberdayaan ibu-ibu kelompok PKK RW IV dan RW V melalui pengolahan tanaman herbal menjadi produk minuman instan. Tahapan yang dilakukan antara lain : 


\section{INTEGRITAS :JurnalPengabdian}

Vol 3, No 1, Juli 2019

ISSN 2580-7978 (Cetak) ISSN 2615-0794 (Online)

\section{Sosialisasi program}

Kegiatan sosialisasi ini memiliki tujuan yaitu untuk memberi gambaran mengenai program IbM yang akan dilaksanakan, dimana di dalamnya tercakup latar belakang, tujuan, dan bagaimana kegiatan akan dilakukan. Selain itu juga untuk memberikan pemahaman dan motivasi kepada peserta agar peserta dapat berpartisipasi aktif dalam pelaksanaan program sehingga tujuan program $\mathrm{IbM}$ dapat terwujud.

Pelatihan pengolahan tanaman herbal menjadi minuman instan

Pelatihan ini bertujuan agar kelompok mitra memiliki keterampilan dalam pengolahan tanaman herbal menjadi produk minuman instan. Pelatihan ini akan dilakukan sebanyak 3 kali. Dalam pelatihan ini menyediakan pemateri, alat, serta bahan yang akan digunakan selama pelatihan. Sedangkan kelompok mitra berperan dalam penyediaan tempat serta peserta pelatihan. Berbagai kendala yang muncul selama pengolahan tanaman herbal akan dibahas pada pelatihan ini.

\section{Analisis kandungan gizi produk olahan}

Tahapan ini bertujuan untuk mengetahui komposisi proksimat produk minuman instan herbal yang telah berhasil dibuat oleh mitra. Komposisi yang dianalisis antara lain kadar air, karbohidrat, protein, lemak, dan abu. Hasil dari analisis nantinya akan ditampilkan pada kemasan produk sehingga konsumen dapat mengetahui kandungan gizi dari minuman instan herbal tersebut. Untuk proses analisis ini dapat diujikan ke laboratorium terkait.

\section{Pelatihan regulasi pangan}

Pelatihan ini bertujuan untuk memberikan pengetahuan bagi para ibu tentang pentingnya pendaftaran produk yang telah dihasilkan. Pada pelatihan ini akan disampaikan mengenai sistem pelabelan, hingga cara mendaftarkan produk untuk mendapatkan nomor PIRT. Diharapkan para mitra akan dapat membuat merk dagang dari produk yang dibuat dan mendaftarkan produknya sehingga produk yang dihasilkan legal untuk dipasarkan. 


\section{INTEGRITAS :JurnalPengabdian}

Evaluasi

Evaluasi dilakukan untuk memperbaiki setiap kekurangan yang ditemukan selama pengabdian dilaksanakan. Setiap kegiatan dievaluasi dan perbaikan dilakukan berdasarkan hasil evaluasi tersebut.

\section{HASIL DAN LUARAN YANG DICAPAI}

Metode pendekatan yang digunakan dalam pelaksanaan pengabdian yaitu pemberdayaan ibu-ibu kelompok PKK RW IV dan RW V melalui pengolahan tanaman herbal menjadi produk minuman instan. Tahapan yang telah dilakukan antara lain :

1. Sosialisasi program

2. Pelatihan pengolahan jahe menjadi minuman jahe instan

3. Pelatihan pengolahan kencur menjadi minuman beras kencur instan

4. Pelatihan pengolahan kunyit menjadi minuman kunyit asam instan

5. Analisis kandungan gizi produk olahan

6. Perizinan PIRT

Berdasarkan pengabdian yang telah dilaksanakan, maka diperoleh hasil sebagai berikut :

\section{Sosialisasi program}

Sosialisasi program ini dilakukan dengan memberikan paparan kepada peserta pengabdian mengenai rencana kegiatan pengabdian yang akan dilakukan. Peserta sosialisasi ini berasal dari RW IV dan RW V. Beberapa hal yang disampaikan pada kegiatan ini antara lain :

a. Tujuan dari kegiatan pengabdian. Kegiatan pengabdian IbM ini bertujuan untuk memberdayakan para ibu rumah tangga di RW IV dan RW V Kelurahan Banyumanik Kecamatan Banyumanik Kota Semarang melalui pengolahan minuman herbal instan.

b. Peserta pengabdian, yaitu para ibu rumah tangga dari RW IV dan RW V Kelurahan Banyumanik Kota Semarang yang belum memiliki penghasilan 


\section{INTEGRITAS :JurnalPengabdian}

Vol 3, No 1, Juli 2019

ISSN 2580-7978 (Cetak) ISSN 2615-0794 (Online)

tetap namun memiliki keinginan kuat untuk menjadi wirausaha melalui pengolahan produk pangan

c. Tahapan kegiatan pengabdian yang akan dilakukan, yaitu sosialisasi, pelatihan, analisis, regulasi, dan evaluasi.

Sosialiasi program berjalan dengan lancar dimana hal tersebut ditunjukkan dengan antusiasme para ibu dalam mengikuti program pengabdian ini. Selama sosialisasi berlangsung, beberapa pertanyaan diajukan oleh ibu-ibu peserta sosialisasi terutama menyangkut mengenai kegiatan pengabdian yang akan dilakukan di RW nya. Luaran yang dicapai yaitu struktur keanggotaan PKK RW IV dan RW V, dengan pemantapan tugas dan fungsi masing-masing.

Pelatihan pengolahan jahe menjadi minuman jahe instan

Pelatihan pengolahan jahe menjadi minuman jahe instan ini dilakukan di rumah salah satu warga RW IV. Tujuan dari salah satu tahapan kegiatan ini adalah untuk memperkenalkan para ibu-ibu anggota pengabdian dalam mengolah jahe menjadi produk jahe instan siap seduh melalui tahapan pengolahan yang benar dan sesuai dengan prosedur. Ibu-ibu peserta pengabdian antusias mengikuti kegiatan ini. Hal ini dapat dilihat dari ikut sertanya para ibu dalam setiap tahapan pengolahan jahe menjadi jahe instan, mulai dari tahap pengupasan hingga pengemasan.

Bahan dan alat yang digunakan dalam kegiatan ini telah disediakan sebelumnya oleh tim pengabdian sehingga memudahkan para peserta pengabdian untuk mengikuti kegiatan ini. Bahan-bahan yang digunakan dalam kegiatan ini antara lain : jahe emprit, gula pasir, kayu manis, kapulaga, dan air. Proses pengolahan jahe menjadi minuman jahe instan relatif mudah baik dari segi bahan maupun alat yang digunakan sehingga peserta pengabdian dirasa mampu untuk membuat produk tersebut. Luaran dari kegiatan ini adalah produk jahe instan dan formulasinya.

\section{Pelatihan pengolahan kencur menjadi minuman beras kencur instan}

Selain jahe instan, produk yang dibuat adalah beras kencur instan yang memiliki keunggulan lain yaitu rasanya yang dominan manis dan cenderung 


\section{INTEGRITAS :JurnalPengabdian}

Vol 3, No 1, Juli 2019

ISSN 2580-7978 (Cetak) ISSN 2615-0794 (Online)

banyak disukai. Kegiatan ini merupakan rangkaian kegiatan pengabdian, dimana peserta pengabdian juga sangat antusias dalam mengikuti kegiatan pengabdian ini. Bahan, peralatan, serta tahapan pengolahan yang relatif mudah menjadikan produk beras kencur instan cukup potensial untuk dikembangkan oleh ibu-ibu Kelurahan Banyumanik. Bahan utama pembuatan beras kencur instan ini antara lain : kencur, beras, gula pasir, dan air. Setelah dilakukan kegiatan pelatihan pembuatan jahe instan dan beras kencur instan, beberapa hari kemudian ibu-ibu posdaya dari RW IV mengikuti bazaar yang diselenggarakan oleh Kecamatan Banyumanik. Dalam bazaar tersebut, selain makanan kering hasil produksi ibuibu RW IV, produk jahe instan dan beras kencur instan juga ikut dipamerkan dan dijual, serta mendapat sambutan yang cukup positif dari konsumen. Luaran dari kegiatan ini adalah produk beras kencur instan dan formulasinya.

Pengolahan kunyit menjadi minuman kunyit asam instan

Tahapan kegiatan ini merupakan tahapan lanjutan dari tahapan-tahapan sebelumnya. Dengan fokus tetap pada pengolahan tanaman herbal, pengolahan kunyit menjadi produk kunyit asam instan juga diikuti dengan antusias oleh para ibu-ibu dari RW IV dan RW V. Jika dilihat dari proses pembuatan dan bahannya, kunyit asam instan memiliki sedikit perbedaan dalam pengolahannya. Asam jawa yang digunakan sebagai pemberi rasa asam ternyata menghambat proses pengkristalan sehingga penggunaan asam jawa digantikan dengan asam sitrat. Selain mudah didapat, asam sitrat juga memiliki harga yang terjangkau. Rasa yang dihasilkan juga cenderung sama dengan kualitas warna kuning hasil seduhan yang lebih baik. Umumnya para peserta pengabdian memiliki ketertarikan yang besar terhadap produk tersebut sebagai salah satu produk unggulan di posdanya masing-masing RW nya. Luaran dari kegiatan ini adalah produk kunyit asam instan dan formulasinya

\section{Analisis kandungan produk olahan}

Produk pangan hasil olahan memiliki kandungan gizi yang berbeda. Hal tersebut dipengaruhi oleh bahan yang digunakan serta proses pengolahan produk tersebut. Untuk mengetahui kandungan gizi pada jahe instan, beras kencur instan, 


\section{INTEGRITAS :JurnalPengabdian}

Vol 3, No 1, Juli 2019

ISSN 2580-7978 (Cetak) ISSN 2615-0794 (Online)

dan kunyit asam instan perlu dilakukan pengujian laboratorium. Produk hasil olahan ibu-ibu RW IV dan RW V Kelurahan Banyumanik telah dibawa ke laboratorium Teknologi Pangan Universitas Katolik Soegijapranoto untuk dianalisis kadar proksimatnya akan diketahui nilai gizinya. Produk dikemas dalam kemasan 150 gram dengan sajian per kemasan sebesar 25 gram. Dari hasil pengujian tiap sajian kemasan ketiga jenis produk, didapatkan hasil seperti yang dapat dilihat pada Tabel 1 berikut ini

Tabel 1. Hasil Pengujian Minuman Herbal Instan

\begin{tabular}{llccccc}
\hline No. & \multicolumn{1}{c}{ Sampel } & $\begin{array}{c}\text { Air } \\
\mathbf{( \% )}\end{array}$ & $\begin{array}{c}\text { Abu } \\
\mathbf{( \% )}\end{array}$ & $\begin{array}{c}\text { Protein } \\
\mathbf{( \% )}\end{array}$ & $\begin{array}{c}\text { Lemak } \\
\mathbf{( \% )}\end{array}$ & $\begin{array}{c}\text { Karbohidrat } \\
\mathbf{( \% )}\end{array}$ \\
\hline 1 & Jahe Instan & 1.515 & 0.387 & 0.687 & 0.040 & 97.372 \\
2 & Beras Kencur Instan & 1.938 & 0.138 & 0.359 & 0.209 & 97.357 \\
3 & Kunyit Asam Instan & 0.313 & 0.213 & 0.197 & 0.118 & 99.158 \\
\hline
\end{tabular}

\section{Perizinan PIRT}

Perizinan PIRT dilakukan untuk mendapatkan nomor PIRT sehingga produk pangan yang dikemas memiiki ijin untuk diedarkan. Proses yang dilakukan untuk mendapatkan nomor PIRT cukup rumit karena harus menunggu beberapa waktu. Namun begitu sosialisasi untuk penerbitan nomor PIRT telah dilakukan dan warga telah mendaftarkan produknya ke Dinkes Kota Semarang untuk kemudian menunggu giliran peninjauan dari Dinkes. Pada tahapan sosialisasi penerbitan nomor PIRT, antusiasme ibu-ibu cukup besar. Hal ini dapat dilihat dengan banyaknya produk yang ingin didaftarkan nomor PIRTnya.

\section{UCAPAN TERIMA KASIH}

Tim pengabdi mengucapkan terimakasih kepada Direktorat Riset dan Pengabdian Masyarakat, Kementerian Riset, Teknologi, dan Pendidikan Tinggi (Kemenristek dikti) atas didanainya program pengabdian kepada masyarakat ini. 


\section{DAFTAR PUSTAKA}

Afifah, N., Shilichah, E., Edy, C., 2011. Rancangan Produksi Minuman Instan Skala Industri Kecil dari Empon-empon. Prosiding SnaPP2011 Sains, Teknologi, dan Kesehatan.

Anonim a , 2014. Peta Wilayah Kelurahan Banyumanik. http://kelurahanbanyumanik.blogspot.co.id/2014/02/peta-wilayahkelurahan-banyumanik.html. Diakses pada 17 April 2016

Anonim ' ${ }^{c}$, 2014. Pelaksanaan Kegiatan 10 Program Pokok Pkk Tim Penggerak PKK Kelurahan Banyumanik Kecamatan Banyumanik Kota Semarang Tahun 2014. $\quad$ http://pkk-kelbmk.blogspot.co.id/2014/04/profil.html. Diakses pada 18 April 2016

Bappeda dan BPS Kota Semarang. 2012. Banyumanik dalam Angka 2011. Pemerintah Kota Semarang

Marwati, Tri. 2013. Teknologi Pascapanen Tanaman Obat. Balai Besar Penelitian dan Pengembangan Pascapanen Pertanian. Bogor

Tangkeallo, C., dan Widyaningsih, T. D., 2014. Aktivitas Antioksidan Serbuk Minuman Instan Berbasis Miana Kajian Jenis Bahan Baku dan Penambahan serbuk Jahe. Jurnal Pangan dan Agroindustri Vol.2 No.4.

Wijayakusuma, Hembing. 2000. Potensi Tumbuhan Obat Asli Indonesia Sebagai Produk Kesehatan. Risalah Pertemuan Ilmiah Penelitian dan Pengembangan Teknologi Isotop dan Radiasi 